\title{
Islam in V.S. Naipaul's Beyond Belief: Viewed from an Erroneous Perspective
}

\author{
Abul Mobrur Mohammad Hamed Hassan \\ Assistant Professor of English, Centre For University Requirement Courses (CENURC) \\ International Islamic University Chittagong \\ Bangladesh
}

\begin{abstract}
V.S. Naipaul's 'Beyond Belief', subtitled Islamic Excursions Among the Converted Peoples is a travelogue where he deals with his travels in four non Arab Muslim countries. He describes interviews with different people and different situations to show the effects of Islam on people and countries not belonging to the Arab world. Although he claims to be objective, he can't hold it in his narrative style, language, choice of people to be interviewed and occasional comments. He actually attacks Islam deliberately. Throughout the book his attitude is biased. He doesn't hesitate to term Islam as imperialism and the Muslim as a backward nation. He attacks everything which is Islamic. Mosques, the adhan, Islamic literature, Islamic dress and Muslim households also fall victims to his attack. Naipaul has earned a great popularity among the Western readers, most probably because of his misrepresentation of Islam. Western critics think him to be an authority on Islam in action. While admiring him the western critics do not think that Naipaul's lack of knowledge about Islamic ideology or his deliberate prejudice against Islam is the cause of his misrepresentation of Islam.
\end{abstract}

Key words: Travelogue, Misrepresentation, Islam, Islamophobia, prejudice

\section{Introduction:}

Sir Vidiadhar Surajprasad Naipaul, better known as V. S. Naipaul, is a Trinidadian-born British novelist of Hindu heritage and Indo-Trinidadian ethnicity. Naipaul has 22 books (both fiction and nonfiction) to his credit. In his two travelogues, Among the Believers: an Islamic Journey and Beyond Belief he deals with his travels in four predominantly Muslim but non-Arab countries namely Indonesia, Malaysia, Pakistan and Iran, which he had visited. In these two travelogues he misinterpreted Islam terming it as an Arab religion and an imperialism which has weakened all non Arab Muslims. This article tries to show a true picture of Islam with a view to showing that Naipaul's views are wrong and thus should be rejected by the cautious readers.

\subsection{Novelist V.S. Naipaul:}

V.S. Naipaul has occupied a prestigious position as a novelist in the mainstream Western culture. The publication of his two travel narratives has made him a famous writer in the eyes of Western writers. With specific reference to "Islamic journey'(s) various Western critics have praised him for his "moral integrity" "fearless truth telling" and loyalty to the "proof of evidence". Some critics have even considered the two books as promising "new levels of understanding about Islam" He has enjoyed a reputation as "authority" on the 'Muslim world' in different Western culture. He received a knighthood for his services to literature in 1990, was awarded the David Cohen British Literature Prize by Arts Council of England in 1993 and awarded the Nobel Prize for literature in 2001. However he was severely criticized by the critics beyond the periphery of mainstream western culture for his misrepresentation of Islam in both of his travelogues. He has been referred to as a man "incapable of restraining his loathing for the Islamic world and its people". Some critics have called him "V.S. Nightfall" (Derek Walcott) "a false native informant" (Spivak) "Uncle Tom" and "curmudgeon of contemporary literature in English”(E. Said) etc. (Meddour, 2011, p-22)

\subsection{An overview of Beyond Belief:}

Beyond Belief, subtitled Islamic Excursions Among the Converted Peoples is the second book in Naipaul's travelogues on Islam. His first book on this subject Among the Believers: an Islamic Journey appeared in 1981. The first book Among the Believers deals with his travels to four predominantly Muslim but non-Arab countries, namely Indonesia, Malaysia, Pakistan and Iran. Through this non-fiction book he wanted to expose the effect of Islamic belief on the people of these countries. He wanted to expose that 'fundamentalist monomania' gradually kills a society, destroying tolerance and pluralism and uprooting people from their history. In 1995 he made another five-month journey through the same countries. Beyond Belief is the result of this five-month journey through Indonesia, Iran, Pakistan, and Malaysia. This book is a compilation of 
interviews, interspersed by the author's remarks and judgment. While reading the book one could almost listen to anti-Islamic thoughts of the author, not in whispers, not hidden but in shouts.

In Beyond Belief Naipaul plunders the nineteenth-century novel in order to present a disturbing image of the Muslim world. Having striven to establish himself as a reliable and trustworthy narrator, he presents a landscape in which mosques, the adhan, Islamic literature, Islamic dress and Muslim households combine to generate an oppressive atmosphere in which he can't breathe. Naipaul goes on to mobilize the gothic genre- a genre designed to terrify its readers. Bloodthirsty vampires and immortal beasts take over the minds of their victims and threaten civilization, reason, modernity and sanity. By studying Naipaul's depiction of eerie Muslim households, threatening Islamic artifacts, and brainwashed Muslims at prayer, one can see how his manipulation of the gothic genre culminates in a powerful piece of propaganda. (Meddour, 2011)

The final nineteenth-century narrative stand that pervades Beyond Belief is that of madness. Followers of Islam are repeatedly referred to as violent, irrational, void, confused, numbed by pain and prey to nihilistic form of neurosis. For this reason those who share his hatred of Islam regard Beyond Belief as a "first rate humanist study" of "contemporary Islamic converts." However, the prestigious awards and critical acclaim that Naipaul has received suggest that his Islamophobic world view is disturbingly widespread.

\section{Naipaul's Failure to Keep up Objectivity:}

In the prologue to Beyond Belief Naipaul assures the readers that "This is a book about people. It is not a book of opinion." (Naipaul, 1998, p-1) The readers are guaranteed that the "the truth" will be presented to them in an undistorted manner. He as well promises that the "writer will be less present, less of an inquirer", instead, he will be "in the background, trusting to his instinct." (p-2) Naipaul claims to be pure, natural and instinctive artist. In this manner, he assures the readers that they can rely on his objectivity. But in fact Naipaul has totally failed to keep up this objectivity. His occasional comments, choosing of the situations and people and his narrative style and use of words are misleading. The book can easily mislead the wider non Islamic readership into the belief that Islam is a backward religion, that Islam advocates terrorism and religion fanaticism, that Islamic peoples are adverse to progress and lead miserable lives, that they have no forethought, that they are incapable of competing with the rest of the world. The book fans the already dominant opinion of many that behind every turbaned Muslim, there lives a potential suspect, a terrorist. Here are some points which expose Naipaul's hatred towards Islam and everything that is Islamic.

\subsection{Practicing Muslims cause Naipaul's breathing restrictions:}

On encountering practicing Muslims Naipaul begins to suffer from severe breathing restrictions. He also experiences an accompanying change in air quality. This becomes clear when the readers see Naipaul visiting Imamuddin's office. Imamuddin is a practicing Muslim and he also has a lot of scientific knowledge. Since Naipaul thinks that science and Islam are incompatible, he considers Imamuddin an "unusual man" for his being "a man of science" and "a dedicated man of faith" simultaneously. Despite the kindness that Imamuddin shows to Naipaul, his "Muslimness" causes Naipaul to suffer from unpleasant physical reactions. As Naipaul enters Imamuddin's office he begins to make his inventory of the room.

"On one side of the laptop was a well handled Koran; on the other side was a pile of shoddily produced paperback books, perhaps a foot high, of similar size and in electric blue covers, which had been published in Egypt and might have been a very long commentary on the Koran: no doubt like meat and drink to Imamuddin." $(\mathrm{p}-16)$

Naipaul is safe while Imamuddin remains in the room, but when he answers the adhan (call to prayer) and deserts Naipaul, the very presence of what Naipaul suspects to be a set of "Islamic books" causes serious health problem to him. We are informed that,

"........ without the man himself [......] his missionary paraphernalia felt oppressive [.....]. It was only someone like Imamuddin who could give point and life to the electrical blue Egyptian paperbacks on the glass-topped desk.” (pp19-20)

In his heightened state of anxiety, Naipaul transforms Imamuddin's private reading material into "dangerous missionary paraphernalia" with awesome power. They are the "meat and drink" the life blood upon which Imamuddin apparently survives. The "electric blue" covers suggest that these books are made of hazardous, explosive materials and, being only "shoddily produced" they are in stark contrast to the laptop and glass desk upon which they rest. Naipaul prefers not to ask Imamuddin about the content of these books, for doing so would deflate the passage's tension. Rather he reassures himself with the thought that this possible "commentary on the Koran is something that only a man like Imamuddin could give point and life to." However mere proximity to these potentially "Muslim" books causes him to suffer from the "oppressive" atmosphere that they generate. ( pp19-20) 
Another occasion on which the change in atmospheric quality occurs is when Naipaul visits Mohammad Akram Ranjha at a commune run by, in Naipaul's words, "the most important of the fundamentalist groups: Jamaat-i-Islami". Imprisoned for kidnapping and possibly helping murder his brother's wife (Naipaul's choice of Muslim "interviewees" are far from being, as he claim, "representative") Mohammad is imprisoned and he shares a cell with a "political prisoner". This leads to his "jailhouse conversion". Eventually, a lawyer who we are told "crazed with religion" helps Mohammad get into Law College. While practicing law, Mohammad becomes politically active on behalf of Jamaat-i-Islami.

His son Saleem, a 34 -year-old senior customs officer, agrees to drive Naipaul to the commune on the edge of Lahore. This is when Naipaul realizes that he has made his first major mistake: He failed to accept Saleem's "offer of air-conditioning". Naipaul refused the offer because he feared that he might catch a "chill". He comes to regret this decision because the closer he gets to the commune, the more "choked" he becomes. Significantly, Naipaul's breathing restrictions once again coincide with the call to prayer (like Imamuddin before him, Saleem deserts the afflicted Naipaul in order to go to the mosque) (p 216) When Saleem returns he takes Naipaul to his study and library.

At this point in the journey, Naipaul encounters yet another set of "Islamic books".

"Half the wall facing the door carried those Islamic sets in decorated binding [....] I soon stopped looking at the books. I began to choke in the stale, enclosed air. I felt I was becoming ill." (p-317)

This room of "Islamic learning" appears to be drained of oxygen. We are told that it is "entirely sealed" (by this Naipaul later clarifies that he meant that the window was closed). Naipaul tries to rectify this and demands that someone opens the window and switches on the "air cleaner". Sitting on the only chair in the room, one that has been brought up for him at his specific request, he sits by the window, inhales some 'slightly less polluted air' and begins to recover. But the relief that he enjoys is short-lived, Having survived the 'stifling atmosphere' produced by the adhan, the mosque, Islamic literature and Muslim households, Naipaul's breathing restriction returns during the following dialogue, in which Saleem proudly introduces his son:

Saleem said, "He is going to learn the whole Koran by heart."

'The whole Koran', the old man said, picking up the duet with his son.

I asked, 'How long will that take?'

Saleem said, Five or six years.'

I couldn't stay. My breathing had become very bad. Downstairs, the servants, thin and dark and dingy, behind the sacks with the split golden paddy. Outside, the fumes and girt of the Multan road. Saleem's driver drove me back to the hotel. Saleem didn't come with me. (p 321)

Naipaul's reaction to the tradition of learning to recite the Qur'an is so violent that he flees back to the relative safety of his hotel in Lahore without delay. The little boy is left unheard.

As one can see from these passages, Naipaul's fear of Islamic literature, mosques, or indeed any form of Muslim worship are clearly reflected in both his environment and his physical ailments. In Beyond Belief, poor air quality is an indicator of the Islamic faith, and Naipaul's asthmatic responses are symptomatic of the emotions that he experiences during close encounters with Muslims. (Meddour, 2011, p-62)

\subsection{Naipaul views the Muslims as gothic novel characters:}

One of the main nineteenth-century literary genres that Naipaul mobilizes in his "Islamic" travelogue is a style called "gothic realism". The typical plot of the nineteenth-century gothic novel is that of the delicate but curious heroine who is lured into the ancestral home of a seemingly innocent but fearsomely dangerous count or aristocrat. Naipaul recycles this plot, placing himself at the center. It goes like this. The inquisitive Naipaul visits Imamuddin's house in order to "hear a little more about his past-his ancestry." (Naipaul, 1998, p-41) But he arrives late and to his disdain, is left to wait in an empty room. Once again he fulfils the familiar role of the "realist observer" and describes the objects in the room:

On the pillar of the sitting room there were two or three decorative little flower pieces and surprisingly, a picture of a sailing ship. About the sitting room were small mementoes of foreign travel, tourist souvenirs, showing a softer side of Imamuddin (or his wife), a side not connected with mental training, if indeed the house was theirs, and if their mementoes had truly tugged at their hearts (and did not, rather, preserve the memory of some pious giver. (pp-42-43)

In Naipaul's view, Islamic education ("mental training") is incompatible with a love of travel, sentimentality, or a liking for nautical scenes. Therefore the collection of "sentimental objects" becomes suspicious and Naipaul doubts whether the house actually belongs to Imamuddin and his wife. The implication is that these comforting objects are being displayed in order to lure him into a false sense of security. Naipaul's nerves get the better of him as he waits for Imamuddin, and he begins to experience a deep sense of panic, 
...how long [...] should I stay where I was, violating the house, and how when the time came [...] might I get away from the curious trap I had appeared to have fallen into. (p-43)

Naipaul uses gothic language to portray both Islam and Muslims throughout Beyond Belief. In the section on Indonesia, Islam is described as having spread in Dracula-like fashion:

Islam had come here not long before Europe. It had not been the towering force it had been in other converted places. [...] It had not completely possessed the souls of people. ( $p-24)$

We need only to study his description of Muslims (or "possessed souls") answering the adhan in order to see the use of the gothic genre in his narration.

.... within the office, no doubt from the carpeted and rumpled open space at the end of the corridor, hesitant scraping sounds developed into a shy chant.[...]The chanting from the corridor became more confident. It couldn't be denied now. I could see that Imamuddin wanted to be there, with the chanters and the prayers. The chanting now filled the corridor [...] he couldn't be held back. (pp-18-20)

The passage is infused with gothic tension: "hesitant scraping sounds" and rising "chants" suggest the actions of a frightening and possibly subhuman sect, rather than a group of Muslims at prayer. In Naipaul's view, by merely answering the call to prayer, Imamuddin reveals himself to be one of the walking dead, a mindless being seduced against his will, for "he couldn't be held back."

The gothic genre is dominated by vulnerable characters who submit their will, often subconsciously, to a higher demonic force that feeds off their life blood and leaves them void. In Naipaul's view, the men who are "unable to resist" the call to prayer and the women who "muzzle themselves" have signed such a contract of submission and have agreed to abolish "the self." Naipaul repeatedly asserts that Islam demands that people annul their individuality. With regards to Pakistan, he argues that "the fundamentalists wanted people to be transparent, pure, to be empty vessels for the faith. It was an impossibility: human beings could never be blanks in that way." (p-311)

\subsection{Naipaul regards non Arab Muslims as converts suffering from neurosis:}

Naipaul's evident concern with the mental health of Muslims constitutes another area of similarity between Beyond Belief and nineteenth century literature. Mental instability became a preoccupation in nineteenth century fiction. Central characters here are increasingly unstable. Naipaul places the Muslims in place of these characters. He thinks that all non Arab Muslims are converts and therefore they suffer from neurosis and have a tendency towards nihilism and self delusion.

Islam in its origin is an Arab religion. Everyone not an Arab who is a Muslim is a convert. Islam is not simply a matter of conscience or private belief. It makes imperial demands. A convert's world view alters. His holy places are in Arab lands; his sacred language is Arabic. His idea of history alters. He rejects his own; he becomes whether he likes it or not, a part of the Arab story. The convert has to run away from everything that is his. The disturbance for societies is immense, and even after a thousand years can remain unresolved; the turning away has to be done again and again. People develop fantasies about who and what they are; and in the Islam of converted countries there is an element of neurosis and nihilism. These countries can be easily set on the boil. $(p-1)$

\section{Causes behind Misrepresentation of Islam:}

Professor Golam Gaus Al-Quaderi and Md. Habibullah (2012) in their study of Naipaul's Beyond Belief have found that Naipaul's limitation of vision, Islamophobia, deeply rooted prejudice and misconception about Islam are some of the causes of his misrepresentation of Islam.

\subsection{Limitation of Vision:}

When Naipaul writes 'Islam is in its origins an Arab religion. Everyone not an Arab who is a Muslim is a convert' (p-1) he exposes how his vision is limited. Because of the limited vision he doesn't want to realize that Islam is a universal religion. Naipaul thinks that non Arab Muslims are suffering from various types of misfortune because of their being converted Muslims. Naipaul never ponders upon the simple fact that all existing religions must have been accepted, initially or later as a conversion from one system of belief to another and all initial adherents to any new religion are converts. For example, the European and American Christians are converted people because their religion originated from Palestine, the birth place of Jesus Christ. One critic interrogates Naipaul succinctly thus "One might very well ask him if he thinks that the majority of Hindus these days are converts since it is not an indigenous Indian religion, but was brought along by the invading Aryans" (Khan-2001). If non Arab Muslims suffer from neurosis because of being converted Muslims why do all other converted people not suffer from same neurosis? Apart from this, how can Naipaul consider the Muslims of the four visited countries "converts" without taking the fact into consideration that at the genesis of Islam the 
Arabians also converted from their former religion at hand of Prophet? By taking interviews of some persons randomly, Naipaul makes totalizing assumptions in a subtle and twisted way about a rich and diversified religion, culture and civilization like Islam. (Quaderi-2012, p-23)

Naipaul's limitation of view is exposed when he opines that Muslims are like living dead, their brains are anaesthetized by pain and suffering. If Islam is a religion of pain and suffering, why should the 'converted people' maintain and follow it whereas there is no compulsion from the Arabs at presents? Had Islam not been a universal religion it would not have existed till now. Spontaneous acceptance of Islam among the people and sticking to it century after century in the four visited countries prove the futility of Naipaul's allegation against Islam. That is why, in the contemporary times Islam has become a significant presence in Europe and America, where Islam is the second and third largest religion respectively.

Naipaul's limitation of vision is exposed when he terms Islam 'the most uncompromising kind of imperialism'. (Naipaul 1998, p-72) In its most general sense imperialism refers to a formation of an empire, and as such has been an aspect of all periods of history in which one nation extended its domination over one or several neighboring nations. There is a general agreement that the word imperialism as conscious and openly advocated policy of acquiring colonies for economic, strategic and political advantage, did not emerge till 1880 . According to this, any ideology having imperialistic objective must hanker after economic, strategic and political advantage and consequently exploit the colonized. Let it be asked from Naipaul, in Islam who exploits whom financially, strategically and politically. Of course, there is no vested group in Islam. At best it can be said that different groups are using Islam as a weapon of exploitation. But these groups are not at all acknowledged as a mainstream of Islam. Moreover according to Naipaul Islam only allows the Arabs to respect their past and sacred places established during the Holy Prophet. But Naipaul should have remembered that the Arabs also emancipated from the age called Jahelia and at that time the Arabs were not permitted to show respect to the pre-Islamic past. It is also notable that conversion could not cause any social disaster to the Arabs, rather it made the society stable as opposed to Naipaul's indication. (Quaderi-2012)

Because of the limitation of vision Naipaul has failed to admit that Islam is a universal religion, not an Arab religion. The Allah of Islam is the sustainer of all humanity all over the world and the main sources of Islam, Quran and Hadith address the humanity, not the people of Arabia and Islam covers the complete life of a man. There are three essential criteria that we need to apply to judge any religion that claims to have universal appeal. Let us consider them, and see whether Islam qualifies for being a universal religion or not.

First and foremost criterion that a universal religion should have is an unquestioned belief in the One and Only God of the whole universe. It should be evident to any thinking person that the very concept of universality, by definition, precludes any chance for "differences or divisions among the powers" that control the universe. If there were more gods than one, there could be differences - in fact, wars - among the gods, and the people who favor one god over another would be at loggerheads. Allah says:

If there were, in the heavens and the earth, other gods besides Allah, there would have been confusion in both! but glory to Allah, the Lord of the Throne: (High is He) above what they attribute to Him! (Al-Anbiyaa' 21:22)

The perfect harmony existing among the Sun, the Moon, the planets, and the stars, declares the oneness of the Creator as well as the uniformity of the laws that govern them. The relatively young science of ecology has brought out more facts about the interdependence and coherence existing between the disparate parts of the universe. Indeed, all evidence in the universal order and nature unanimously proclaim the oneness of God. And believers are admonished to observe, study, and ponder over the phenomena of nature to be convinced of this stupendous fact:

Behold! in the creation of the heavens and the earth; in the alternation of the night and the day; in the sailing of the ships through the ocean for the profit of mankind; in the rain which Allah sends down from the skies, and the life which He gives therewith to an earth that is dead; in the beasts of all kinds that He scatters through the earth; in the change of the winds, and the clouds which they trail like their slaves between the sky and the earth;- (Here) indeed are Signs for a people that are wise. (Al-Baqarah 2:164)

As for Islam, its core is absolute monotheism (in Arabic tawheed). Its first and foremost creed is an assertion in simple words: "There is no one worthy to be worshipped, but Allah (God)." This statement is the solid foundation on which the religion of Islam stands. Allah says in the Quran what means,

[Say: He is Allah, the One and Only Allah, the Eternal, Absolute; He begetteth not, nor is He begotten; And there is none like unto Him.] (Al-Ikhlas 112:1-4) 
These verses as well as others in the Quran categorically and emphatically affirm the oneness of the Creator. And Islam declares that God has absolute dominion and control of the whole of creation, and He is the Sustainer and Law-Giver of the universe and everything in it.

The second essential quality of a universal religion is that it is meant for the whole of humanity, irrespective of tribe, race, nationality, and so on. Certainly such a religion should not give any tribe, race, or nation precedence over another. If a religion favors one race, for instance, as "the Chosen People", there is no question of its being a universal religion. Caste-ism, where people are divided into castes, with one caste being superior to another, is another example of this kind of "favoritism". In sharp contrast to such beliefs, Islam strongly upholds the oneness of God as well as the oneness of humanity. God stated in the Quran:

O men! Behold, We have created you all out of a male and a female, and have made you into nations and tribes, so that you might come to know one another. Verily, the noblest of you in the sight of God is the one who is most deeply conscious of Him. Behold, God is all-knowing, all-aware (Al-Hujurat 49:13)

Equality of all humans before God is a concept of Islam derived directly from the oneness of God. One God, one humanity, and one religion for mankind, is the foundation of Islam.

Thirdly, a universal religion should be a complete religion, so that it does not leave the moral principles that should govern the affairs of humans to the whims and prejudices of any particular person or group. Islam is a complete way of life. When we read the Quran or the Prophetic traditions, we find instructions and guidelines relevant to all aspects of life, including the political and economic affairs as well as the ethical and cultural aspects. In fact, Islam does not recognize any kind of separation between religion and life. It has nothing to do with the idea of a separation between church and state, for everything should be dedicated to God alone, and a Muslim is required to submit himself completely and without reservation to the Will of God in all his affairs. A Muslim is commanded to declare,

Truly, my prayer, my worship, my living and my dying are for Allah, the Lord of the worlds. No partner has He: this am I commanded, and I am the first of those who submit to His Will. (Al-An 'am 6:162)

Islam has established a clear system of worship, civil rights, laws of marriage and divorce, laws of inheritance, code of dress, behavior and manners; and how to worship God. It also gives the rules of governance as well as the rules of war. Considering these three criteria, it is only logical to conclude that Islam does indeed have universal relevance. By studying the main sources of Islam, the holy Quran and Hadith, one can understand that Islam is not meant for the people of Arabia or any particular race or country. It is rather a universal religion meant for the whole mankind all over the world and the people of all ages. So Naipaul's view that Islam is an Arab religion basically is totally wrong.

Because of the limitation of vision Naipaul fails to realize that in Islam all men are equal, whatever be their color, language, race or nationality. Islam addresses itself to the conscience of humanity and dissolves all false barriers of race, status and wealth. There can be no denying the fact that such barriers have always existed, and do exist even today in this so-called enlightened age. Islam removes all these impediments and proclaims the idea of the whole humanity being one family of God. This is why the prophet (pbuh) taught us that all creatures of Allah form the family of Allah and the person who shows the best love to His creatures is the dearest to Him. Historian Toynbee has made some interesting observations in this respect. In 'Civilization on Trial' he writes: 'Two conspicuous sources of danger-one psychological and the other material-in the present relation of this cosmopolitan proletariat (i.e., westernized humanity) with dominant element in our modern Western society are race consciousness and alcohol, and in the struggle with each of these evils the Islamic spirit has a service to render which might prove, if it were accepted, to be of high moral and social value.' 'The extinction of race consciousness as between Muslims is one of the outstanding moral achievements of Islam, and in the contemporary world there is, as it happens, a crying need for the propagation of this Islamic virtue. It is conceivable that the spirit of Islam might be the timely reinforcement which would decide this issue in favor of tolerance and peace.' (Toynbee, 1957 pp-205-299)

Naipaul's limitation of vision is exposed through the incongruity between his words and real situation. Naipaul visited the four non-Arab Muslim countries in 1980 (Iran, Pakistan, Malaysia and Indonesia) and his aim was to "see Islam in action" and "to find out about the application of Islam to institutions, to government, to law." (Naipaul, 1998, pp-103,113) But he did not ponder upon the post colonial trauma and the existing sociopolitical situation of the visited countries during 1980s. Malaya was restructured as the Federation of Malaysia in 1948 and secured independence on 31 August 1957 from British regime. Malaya united with Sabah Sarawak and Singapore on 16 September 1963 took the name Malaysia. Following three and a half centuries of Dutch 
colonialism, Indonesia gained its independence after World War II. Pakistan gained independence from the British Empire in 1947, after a long struggle. In 1953 Iran became an authoritarian regime, following a coup detat instigated by the USA and UK. Growing dissent with foreign influence culminated during the Iranian Revolution which led to establishment of an Islamic Republic on 1 April 1979. So it is clear that those four visited countries were influenced by colonial power directly and indirectly and were consequently undergoing a turbulent time. All the above mentioned countries in the period covered by the two travelogues were experimenting in different degrees to be Islamic in a world dominated by Western neo-colonialism and modernity. (Quaderi-2012, p 28)

In fact, the Muslims, not only in these four countries but also all over the Muslim world, have been victimized by the enemies of Islam. They are defeated, massacred, double crossed, colonized and exploited, proselytized, Westernized and de-Islamized by internal and external agents of their enemies. In today's global mass media, the 'Muslim' is stereotyped as aggressive, destructive, lawless, terrorist, uncivilized, fanatic, fundamentalist, backward and anachronistic. The Muslim Ummah is divided against itself. The colonial powers have successfully fragmented the Ummah into some fifty or more nation-states and set them one against another. The boundaries of the Muslim states have been so defined as to create perpetual friction for every state with its neighbors. Political machination by the enemies continually exploits those areas of friction and creates feelings of alienation and hostility. Through the Muslim world except in a few regions where the enemy has found rulers ready to cooperate, colonial administration has destroyed all political institutions in the land. When the time came for colonial administrations to withdraw, they entrusted power to the native elites who had already been systematically Westernized. The colonial powers have destroyed the economy of the Muslim world. The production of goods and services in the Muslim world is far below their needs. Even in the strategic necessities of life-the staple foods, clothing, energy and hardware-no Muslim state is fully self sufficient. Every Muslims state has become so dependent upon the colonial powers that, if for any reason colonial powers wish to stop their unfair trade with it, it will be exposed to famine. Everywhere, colonial interest has been creating consumer markets and demand for colonialists' products, while the need of Muslims for productive hardware goes unheeded. The colonialists attacked everything Islamic either directly or by the native puppets. The perfection of the Quranic test, the Message of the Prophet (pbuh), the veracity of the Sunnah, the comprehensiveness of Shariah and the glories of the Muslim achievements in culture and civilization are severely denigrated. The colonialists and their stooges filled the Muslim daily life with media products that promoted Western culture. In this way the Muslim Ummah has been weakened.

\subsection{Islamophobia:}

Naipaul's fear of Islam keeps him away from trying to know more about Islam by studying the main sources of Islam. He is afraid of everything which is Islamic. He suffers from physical ailment, breathing restrictions and feels choked when he comes in contact with Islamic rituals like adhan and salah and Islamic literature. Islamophobia did not allow Naipaul to think over the works of the Muslims in the four countries, and he explained the works in a twisted and distorted manner. Naipaul thinks Imamuddin an "unusual man" because he is a man of science and a dedicated man of faith". According to Naipaul, science and Islam are incompatible and, therefore, can not go together. It is beyond imagination that a great scholar, a Nobel laureate like Naipaul doesn't have any idea of the contributions of Muslims towards since. Undoubtedly, Islamophobia, his fear of Islam and everything that is Islamic barred him to look into the glorious history of the Muslims and their contributions towards science and other branches of knowledge.

Naipaul should have known that seeking knowledge is obligatory in Islam for every Muslim, man and woman. The main sources of Islam, the Quran and the Sunnah (Prophet Muhammad's traditions), encourage Muslims to seek knowledge and be scholars, since this is the best way for people to know Allah (God), to appreciate His wondrous creations and be thankful for them. Following these instructions Muslims have always been eager to seek knowledge, both religious and secular, and within a few years of Muhammad's mission, a great civilization sprang up and flourished. The outcome is shown in the spread of Islamic universities. AlZaytunah in Tunis, and Al-Azhar in Cairo go back more than 1,000 years and are the oldest existing universities in the world. Indeed, they were the models for the first European universities, such as Bologna, Heidelberg, and the Sorbonne. Even the familiar academic cap and gown originated at Al-Azhar University. Muslims made great advances in many different fields, such as geography, physics, chemistry, mathematics, medicine, pharmacology, architecture, linguistics and astronomy. Algebra and the Arabic numerals were introduced to the world by Muslim scholars. The astrolabe, the quadrant, and other navigational devices and maps were developed by Muslim scholars who played an important role in world progress, most notably in Europe's age of exploration. Here are only a few examples of Muslim contributions in different branches of knowledge. 


\subsubsection{Geography}

Muslim scholars paid great attention to geography. In fact, the Muslims' great concern for geography originated with their religion. The Quran encourages people to travel throughout the earth to see God's signs and patterns everywhere. Islam also requires each Muslim to have at least enough knowledge of geography to know the direction of the Qiblah (the position of the Ka'bah in Makkah) in order to pray five times a day. Muslims were also used to taking long journeys to conduct trade as well as to make the Hajj and spread their religion. The far-flung Islamic empire enabled scholar-explorers to compile large amounts of geographical and climatic information from the Atlantic to the Pacific.

Among the most famous names in the field of geography, even in the West, are Ibn Khaldun and Ibn Batuta, renowned for their written accounts of their extensive explorations. In 1166, Al-Idrisi, the well-known Muslim scholar who served the Sicilian court, produced very accurate maps, including a world map with all the continents and their mountains, rivers and famous cities. Al-Muqdishi was the first geographer to produce accurate maps in color.

Spain was ruled by Muslims under the banner of Islam for over 700 years. By the 15 th century of the Gregorian calendar the ruler-ship of Islam had been seated in Spain and Muslims had established centers of learning which commanded respect all over the known world at that time. There were no "Dark Ages" such the rest of Europe experienced for the Muslims in Spain and those who lived there with them. In January of 1492 Muslim Spain capitulated to Catholic Rome under King Ferdinand and Queen Isabella. By July of the same year, Muslims were instrumental in helping navigate Christopher Columbus to the Caribbean South of Florida. It was, moreover, with the help of Muslim navigators and their inventions that Magellan was able to traverse the Cape of Good Hope, and Da Gamma and Columbus had Muslim navigators on board their ships.

\subsubsection{Mathematics}

Muslim mathematicians excelled in geometry, as can be seen in their graphic arts, and it was the great Al-Biruni (who excelled also in the fields of natural history, even geology and mineralogy) who established trigonometry as a distinct branch of mathematics. Other Muslim mathematicians made significant progress in number theory.

It is interesting to note that Islam so strongly urges mankind to study and explore the universe. For example, the Noble Quran states:

"We (Allah) will show you (mankind) Our signs/patterns in the horizons/universe and in yourselves until you are convinced that the revelation is the truth." [Noble Quran 41:53]

This invitation to explore and search made Muslims interested in astronomy, mathematics, chemistry, and the other sciences, and they had a very clear and firm understanding of the correspondences among geometry, mathematics, and astronomy.

The Muslims invented the symbol for zero (The word "cipher" comes from Arabic sifr), and they organized the numbers into the decimal system - base 10. Additionally, they invented the symbol to express an unknown quantity, i.e. variables like x. The first great Muslim mathematician, Al-Khawarizmi, invented the subject of algebra (al-Jabr), which was further developed by others, most notably Umar Khayyam. Al-Khawarizmi's work, in Latin translation, brought the Arabic numerals along with the mathematics to Europe, through Spain. The word "algorithm" is derived from his name.

\subsubsection{Medicine}

In Islam, the human body is a source of appreciation, as it is created by Almighty Allah (God). How it functions, how to keep it clean and safe, how to prevent diseases from attacking it or cure those diseases, have been important issues for Muslims. Ibn Sina (d. 1037), better known to the West as Avicenna, was perhaps the greatest physician until the modern era. His famous book, Al-Qanun fi al-Tibb, remained a standard textbook even in Europe, for over 700 years. Ibn Sina's work is still studied and built upon in the East.

Since the religion did not forbid it, Muslim scholars used human cadavers to study anatomy and physiology and to help their students understand how the body functions. This empirical study enabled surgery to develop very quickly.

Al-Razi, known in the West as Rhazes, the famous physician and scientist, (d. 932) was one of the greatest physicians in the world in the Middle Ages. He stressed empirical observation and clinical medicine and was unrivalled as a diagnostician. He also wrote a treatise on hygiene in hospitals. Abul-Qasim Az-Zahrawi was a very famous surgeon in the eleventh century, known in Europe for his work, Concession (Kitab al-Tasrif). 
Other significant contributions were made in pharmacology, such as Ibn Sina's Kitab al-Shifa' (Book of Healing), and in public health. Every major city in the Islamic world had a number of excellent hospitals, some of them teaching hospitals, and many of them were specialized for particular diseases, including mental and emotional. The Ottomans were particularly noted for their building of hospitals and for the high level of hygiene practiced in them.

\subsubsection{Reason behind Naipaul's Islamophobia:}

A general perception is that the $9 / 11$ tragedy is the main cause of Islamophobia in the West, but we have to understand that Islamophobia is not mere product of $9 / 11$, rather it been created persistently as a propaganda against Muslims by various ways, such as books, media etc. throughout the history of the West from the time of crusades. Before the 9/11 incident, the Time Magazine exposed the fact that over 60,000 (sixty thousand) books have been written against Islam by Christian West. During the time of Naipaul's first travel, the most widely discussed event was the Iranian Revolution. In 1979, Ayatullah Ruhullah Khomeni became the leader defeating the pro-western king Reza Shah Pahlavi and the deprived people believed that Islamic rule will be the panacea for the wide spread corruption. As a result of the revolution the Western countries lost control over vast sources of oil. This incident created an anti-Islamic hysteria in the West. Suddenly Islam was a matter of curiosity, interest and phobia. In Pakistan power was grasped by Ziaul Haque who putatively wanted to give the country an Islamic identity and order. Indonesia and Malaysia were being influenced by Islamic groups. But what was common to all four countries was that Islam was apparently transforming itself and was influencing the realm of governance and politics. Prior to this, after the withdrawal of direct colonial rule, both Hindus and Muslims had been demonstrating their own religious culture in the state policy. As a result, the hostility between Hindu dominated India and Muslim oriented Pakistan was getting momentum. For example, the quarrel between Hindus and Muslims regarding the Babri Masjid at Ayoddha in North India was making the two nations fall apart. This is another reason why Naipaul was afflicted with Islamophobia. (Quaderi-2012, p 29) Because of this Islamophobia Naipaul always sees negative aspects in Islam and his both travelogues present Islamophobia infected scenario.

\subsection{Prejudice:}

While attacking Islam Naipaul is driven by prejudice against third world countries. Most of the time like an exiled colonial Naipaul is trying to find a place in a post colonial world and consequently he finds in the third world an inherent disorder of a post colonial society that has been both improved and irreparably damaged by the years of western dominance. Like Joseph Conrad and Rudyard Kipling Naipaul tried to unfold the calamities of the third world thinking its people uncivilized and barbarian in general. This idea is tantamount to Orientalism by Edward Said. Like the European writers, Naipaul is so obsessed with Islam that he has thrown his objectivity out the window while writing about the Muslims and Islam. The anti Islamic writers generally show that the West is superior to the non-West and they are the apostles of civilization. Edward Said perceptively comments:

"Three things have contributed to making even the simplest perception of the Arabs and Islam into a highly politicized, almost raucous matter: one, the history of popular anti Arab and anti Islamic prejudice in the West, which is immediately reflected in the history of orientalism [..........], three: the almost total absence of any cultural position making it possible either to identify with or dispassionately to discuss the Arabs or Islam. (Said-1978, p-26,27)

In his first travelogue Among the Believers Naipaul presents the Western civilization as universal, always in creative process and holds the Muslims bound to take help from them though they don't like their ideology. Naipaul says,

"The West, or the universal civilization it leads, is emotionally rejected. It undermines; it threatens. But at the same time it is needed, for its machines, goods, medicines, warplanes [....] All the rejection of the West is contained within the assumption that there will always exist out there a living, creative civilization, oddly neutral, open to all to appeal to." (Naipaul, 1981, p-168)

Naipaul is so preoccupied by this prejudice that he can't understand the simple fact that the countries such as Pakistan, Indonesia and Malaysia got independence from the western countries only some decades ago and consequently they, as the developing countries, seem to be interested in the western scientific developments. But ideologically they do not like the West because they were the victims of rampant exploitation and oppression during the colonial rule. To be more precise, it is very natural for the third world countries to swing between dependence on and rejection of the western civilization. How can Naipaul attribute this swinging position of the four visited countries as the fault of the Muslims? 


\subsection{Misconception:}

Naipaul's wrong notion and lack of knowledge about Islam is one of the reasons of his misrepresentation of Islam. According to Naipaul Islam is a backward religion and it can give birth to terrorism and religious fanaticism. But Naipaul should have known that before fighting any disease or any epidemic, one should diagnose the symptoms and causes of it, because a correct diagnosis is the precondition for cure. Who are terrorists? Are they truly representing Islam? There are many reasons for terrorism; for example, whenever the possible ways of protest for any group are blocked, the group takes the terrorist path. As Moorehead Kennedy said, some "make efforts not to hear and try instead to blame on the victims of their belief" (Osman 2006, p- 382). So a distinction should be drawn between the legitimate demand or revolution and the criminal acts. Naipaul failed to do so, and therefore Edward Said rightly described the two books Among the Believers and Beyond Belief as "intellectual catastrophe." Naipaul should know that Islam never supports terrorism and murder. According to Islam if anyone slays a human being without a just cause and in a war, it shall be as though he had slain all mankind" (382). Naipaul's misconception comes to a great extent mainly from his ignorance about Islam. He acknowledges this matter in the prologue of Beyond Belief "When I started on that journey in 1979, I knew almost nothing about Islam" (Naipaul, 1998, p-14). According to Naipaul "Islam in its origin is an Arab religion" (p-15). This statement is really offensive to Arabs and non-Arabs alike because although the Quran is in Arabic and the mother tongue of the Prophet Mohammad (pbuh) was Arabic, the Arabs are not given any privileged position in Islam and they are not the chosen people of Allah. In fact in his famous speech during the last pilgrimage, the Prophet of Islam had announced that "no Arab believer can claim an elevated status over a non-Arab except in the depth and sincerity of his or piety" (Malak-2011, p-266)

\section{Conclusion:}

Naipaul is a man of great intelligence, knowledge, expertise and gifts. His narrative style is so persuasive. But it is matter of great regret that he has directed his God gifted gifts against the religion of God and against those people who proclaim the obedience of God. He has adopted such narrative techniques to tarnish the image of Islam and Muslim as may beguile any unconscious reader to the belief that Islam is a backward religion meant for the people of Arabia and all non Arab Muslims have adopted Islam rejecting their own glorious cultures, Islamic belief can't go with scientific achievement simultaneously and all misfortunes and troubles of the Muslim world are caused because of this Islamic belief and because of the conversion of the people of these countries to Islamic belief. In Beyond Belief Naipaul plunders the nineteenth-century novel in order to present a disturbing image of the Muslim world. Having striven to establish himself as a reliable and trustworthy narrator, he presents a landscape in which mosques, the adhan, Islamic literature, Islamic dress and Muslim households combine to generate an oppressive atmosphere in which he can't breathe. Followers of Islam are repeatedly referred to as violent, irrational, void, confused, numbed by pain and prey to nihilistic form of neurosis.

Because of Islamophobia, limitation of vision and prejudice against Islam, Naipaul has not felt any necessity to deal with the glorious and outstanding achievements of the Muslims in almost all branches of knowledge like history, geography, astronomy, mathematics, medicine and science. In stead of pondering over the main sources of Islam he has chosen such situations and such persons as in no way represent Islam. He could have at least pondered over the comments and views of those non Muslim scholars who were greater and more famous than him. It is beyond belief that Naipaul doesn't know what Canon Taylor, Sarojini Naidu, De Lacy O'Leary H.A.R. Gibb, G.B. Shaw, A.J. Toynbee, A.M.L. Stoddard, Edward Montet and W. Montgomery Watt said about Islam. Only two quotations out many will prove that Naipaul's view on Islam is completely based on false notion. About Islam H.A.R. Gibb says, "But Islam has a still further service to render to the cause of humanity. It stands after all nearer to the real East than Europe does, and it possesses a magnificent tradition of inter-racial understanding and cooperation. No other society has such a record of success uniting in an equality of status, of opportunity, and of endeavors so many and so various races of mankind ... Islam has still the power to reconcile apparently irreconcilable elements of race and tradition. If ever the opposition of the great societies of East and West is to be replaced by cooperation, the mediation of Islam is an indispensable condition. In its hands lies very largely the solution of the problem with which Europe is faced in its relation with East. If they unite, the hope of a peaceful issue is immeasurably enhanced. But if Europe, by rejecting the cooperation of Islam, throws it into the arms of its rivals, the issue can only be disastrous for both." (Gibb 1932, p- 379) W. Montgomery Watt says, "I am not a Muslim in the usual sense, though I hope I am a "Muslim" as "one surrendered to God," but I believe that embedded in the Quran and other expressions of the Islamic vision are vast stores of divine truth from which I and other occidentals have still much to learn, and 'Islam is certainly a strong contender for the supplying of the basic framework of the one religion of the future."' (Watt 1983, p- 9). Edward Montet says, "Islam is a religion that is essentially rationalistic in the widest sense of this term considered etymologically and historically. The definition of rationalism as a system that bases religious beliefs 
on principles furnished by the reason applies to it exactly . . . It cannot be denied that many doctrines and systems of theology and also many superstitions, from the worship of saints to the use of rosaries and amulets, have become grafted on the main trunk of Muslim creed. But in spite of the rich developments, in every sense of the term, of the teachings of the Prophet, the Quran has invariably kept its place as the fundamental starting point, and the dogma of unity of God has always been proclaimed therein with a grandeur, a majesty, an invariable purity and with a note of sure conviction, which it is hard to find surpassed outside the pale of Islam. This fidelity to the fundamental dogma of the religion, the elemental simplicity of the formula in which it is enunciated, the proof that it gains from the fervid conviction of the missionaries who propagate it, are so many causes to explain the success of Muhammadan missionary efforts. A creed so precise, so stripped of all theological complexities and consequently so accessible to the ordinary understanding might be expected to possess and does indeed possess a marvelous power of winning its way into the consciences of men." (Montet 1890; Quoted by T.W. Arnold in The Preaching of Islam, London, 1913, pp. 413-414.) To conclude we can say that V.S. Naipaul's view on Islam as expressed in his travelogue Beyond Belief is completely wrong and Islam is viewed here from a biased and erroneous perspective.

\section{Works cited}

[1]. Al-Quaderi, Golam Gaus \& Habibullah, Mohammad (2012). Travels in Absurdity: Islam and V.S. Naipaul. In Journal of Postcolonial Cultures and Societies (JPCS). Vol-3, No.1. Wright State University', US

[2]. Gibb H.A.R.. (1932) Whither Islam, Gollancz, London, p. 379.

[3]. Khan, Mohammed Ayub. (2001) A Nobel for Islamophobia? http://www.islamonline.net/English/ArtCulture/2001/10/article11.shtml

[4]. Meddour, Wendy O'Shea (2011) Gothic Horror and Muslim Madness in V.S. Naipaul's Beyond Belief: 'Orientalist' Excursions Among the Converted People. In The American Journal of Islamic Social Sciences, Herndon, VA 20172-0669 USA.

[5]. Malak, Amin. (2011) Naipaul's Travelogue and the 'Clash of Civilization' Complex. http://thefirst-online.com/naipaulstravelogues-and-the-clash-of-civilizations-complex.html.

[6]. Montet, Edward. (1890) La Propagande Chretienne et ses Adversaries Musulmans. Paris, Quoted by T.W. Arnold in The Preaching of Islam. London, 1913, pp. 413-414

[7]. Naipaul, V.S. (1998), Beyond Belief: Islamic Excursions among the Converted People. London. Little Brown and Company.

[8]. Naipaul, V.S. (1981) Among the Believers: An Islamic Journey, New York: Random House.

[9]. Osman, Mohammad Fathi (2006) Islam Terrorism and Western Misrepresentation. In The Blackwell Companion to Contemporary Islamic Thought, edited by Ibrahim M. Abu Rabi, New York. Blackwell Publishing Limited.

[10]. Said Edward (1978) Orientalism. New York. Penguin

[11]. Toynbee, Arnold J, (1957) Civilization on Trial. London, pp-205-299

[12]. Watt, W. Montgomery, (1983) Islam and Christianity Today. London, 1983, p. 9 